$\xi=$

\title{
Marital fidelity and congregation of Indian sarus crane, Grus antigone antigone in and around Alwara lake of district Kaushambi (Uttar Pradesh), India
}

\author{
Shri Prakash $^{1}$, Ashok Kumar Verma ${ }^{2}$ \\ ${ }^{\text {I} D e p a r t m e n t ~ o f ~ Z o o l o g y, ~ K . A . P . G . ~ C o l l e g e, ~ A l l a h a b a d-211001, ~ U t t a r ~ P r a d e s h, ~ I n d i a ~}$ \\ ${ }^{2}$ Department of Zoology, Govt. P.G. College, Saidabad Allahabad-221508, Uttar Pradesh, India \\ *Corresponding author E-mail:sriprakasht80@gmail.com
}

\begin{abstract}
Sarus crane is a monogamous bird and well known as an eternal symbol of unconditional love, devotion and good fortune. Its occurrence represents a healthy wetland ecosystem. These cranes are large, long-legged and long-necked birds belonging to family: Gruidae, order: Gruiformes, class: Aves and phylum: Chordata. Indian Sarus Crane, Grus antigone antigone is the largest of the crane species found in India. These water birds prefer open habitat like marsh areas, abundantly irrigated paddy fields, grass land and river banks as these areas suit them for foraging, roosting and nesting. It has been showing an increasing population trends in this wetland because its habitat is well suited for its population growth. The present study concerns the survey of Indian Sarus Crane in and around Alwara Lake of District Kaushambi (U.P.) during 2014 with special reference to marital fidelity and congregation. The authors reported a congregation of maximum up to 155 cranes during the study period.
\end{abstract}

Keywords: Indian Sarus Crane; Congregation; Vulnerable; Conservation; Sarus safe zone; Increasing population trends; Alwara lake.

\section{Introduction}

There are three subspecies of sarus cranes, the Indian sarus crane Grus antigone antigone, Eastern sarus crane Grus antigone sharp$i i$ and the Australian sarus crane Grus antigone gilli. Meine and Archibald (1996) gave the first comparative review of these three subspecies. The Indian sarus crane Grus antigone antigone (Linnaeus, 1758) is the world's tallest flying bird (Archibald et al., 2003) and is a non-migratory and only resident breeding crane of the Indian sub-continent (Ali et al, 1980). It has been declared as 'State Bird' by the Government of Uttar Pradesh.

The Indian sarus cranes are omnivorous, eating insects (especially grasshoppers), aquatic plants, seeds, roots, tubers, invertebrates, crustaceans, butterflies, molluscs, fishes, frogs, reptiles and eggs of birds. The population density of sarus crane is inseparably associated with wetland habitats and food availability.

A review of literature suggests that there was only a few attempts to study the demography, ecology and status of Indian sarus crane on large scale in Uttar Pradesh (Chauhan, R. and Kumar D. 2000; Sundar, K.S.G, Chaudhary B.C. and Kaur J. 2000a; Sundar K.S.G., Chaudhary B.C. and Kaur J. 2000b; Sundar, K.S.G. 2010; Jha, K.K 2014; Prakash, S., Narain, S. and Kumar, S. 2014; Ansari, N. A. 2015; Verma at al, 2015. Verma, A.K., Prakash, S. and Kumar Sunil (2016) reported an increasing population trend of Indian Sarus Crane in and around Alwara lake of District Kaushambi (U.P.).

Breeden and Breeden (1982) reported the biggest sarus crane congregation of 434 cranes in Bharatpur (Rajasthan) in December 1979 while Prasad et al, (1993) reported a congregation of 213 cranes in a wetland of Hardoi in Etawah district of Uttar Pradesh on $31^{\text {st }}$ May 1993. Sunder et al, (2003) cited the collection of a data of congregation of 81 cranes in Bidhuna lake of Mainpuri district. Kumar et al, (2015) also worked on congregation of sarus crane in Unnao district of Uttar Pradesh. The present study is therefore concerned with the survey of Indian sarus crane in and around Alwara Lake of District Kaushambi (U.P.) during 2014 with special reference to marital fidelity and congregation.

\section{Study Area}

The lake under exploration, i.e. Alwara lake is located in Sarsawan block of Manjhanpur tahsil of Kaushambi district of Uttar Pradesh (Image 1). The exploration area is more than $75 \mathrm{~km}$ away from Allahabad and $290 \mathrm{~km}$ from Lucknow by road. Its nearest railway station is Bharwari at a distance of $35 \mathrm{~km}$ and nearest airport Bamrauli (Allahabad) is at a distance of $70 \mathrm{~km}$. It is situated between the latitude $25^{\circ} 24^{\prime} 05.84^{\prime \prime} \mathrm{S}-25^{\circ} 25^{\prime} 10.63^{\prime \prime} \mathrm{N}$ and longitude $81^{0} 11^{\prime} 39.49$ 'E- $81^{0} 12$ ' 57.95 "W with altitude MSL -81.08 meter.

The Alwara Lake is a natural lake and now an important perennial wetland, as shown in figure 1 . It is surrounded by agricultural fields and connected to the river Yamuna and covers about several hundred hectares. In this lake, the water level falls during summer and winter but rises during rainy season. The lake has derived its name from the village Alwara. Locally, it is called Alwara Taal. The Alwara lake is surrounded by Paur Kashi Rampur in east, Tikara in the north, Shahpur in the south and the river Yamuna in the west. The most adjoining and influenced village is Paur Kashi Rampur. 


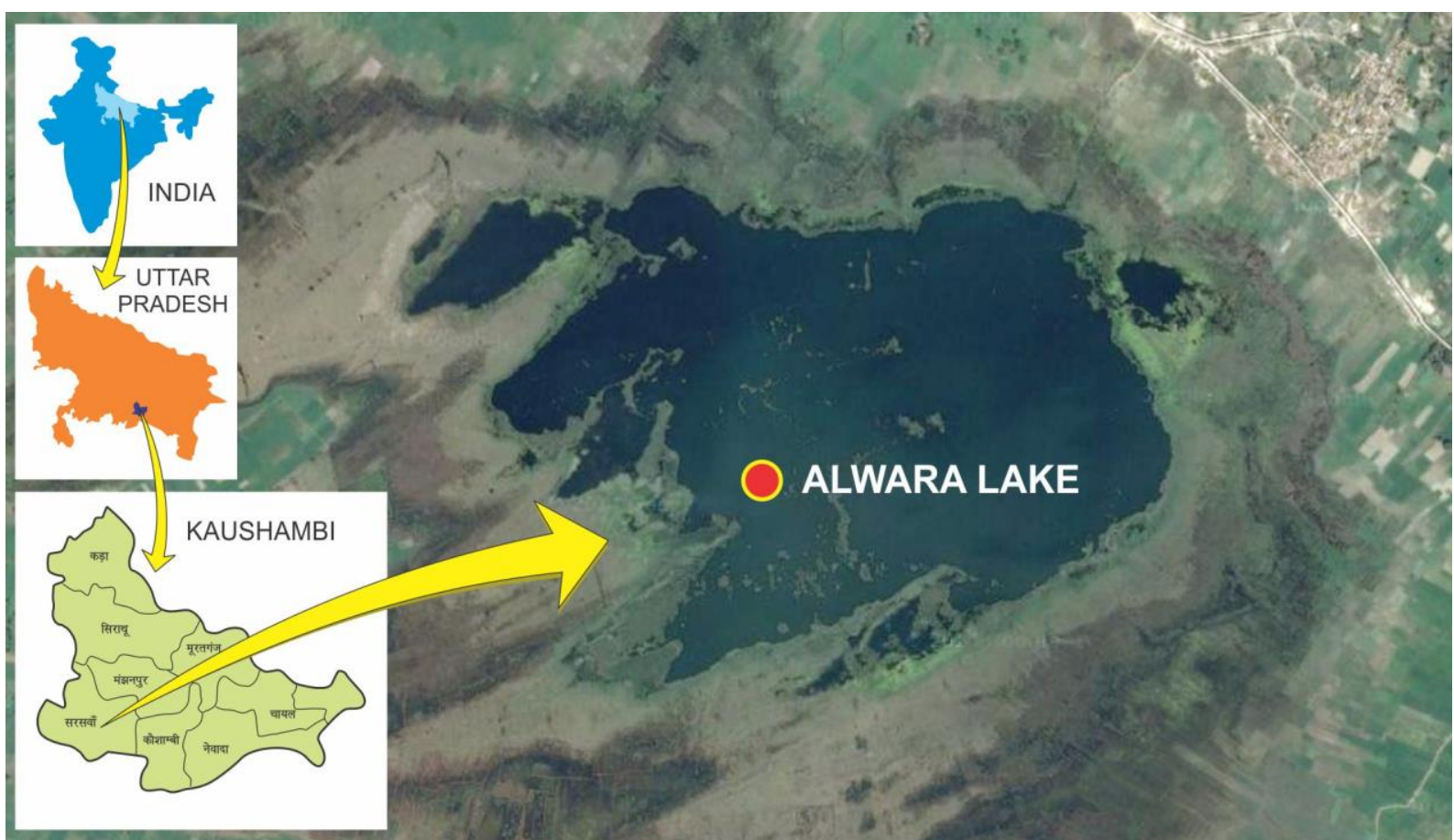

Image 1: Study Area in Kaushambi District of Uttar Pradesh (India).

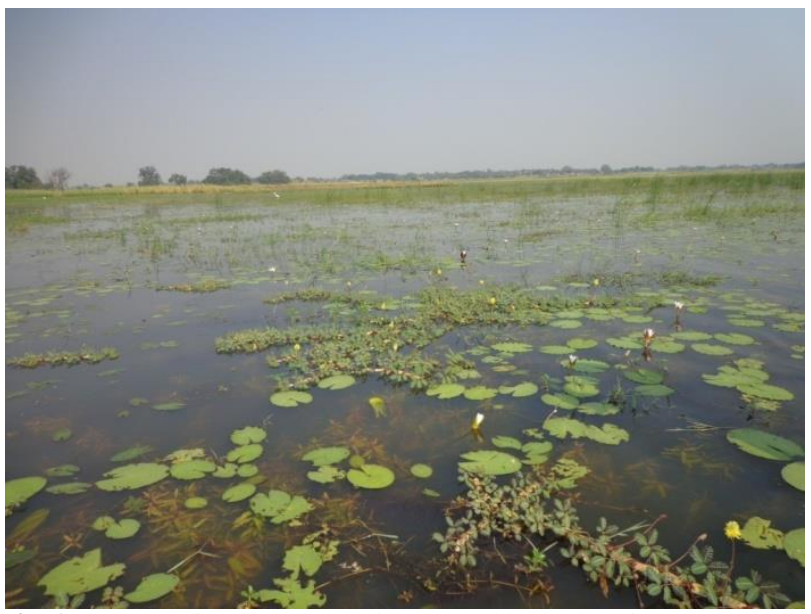

Fig. 1: A View of Alwara Lake of Kaushambi District of U.P. (India).

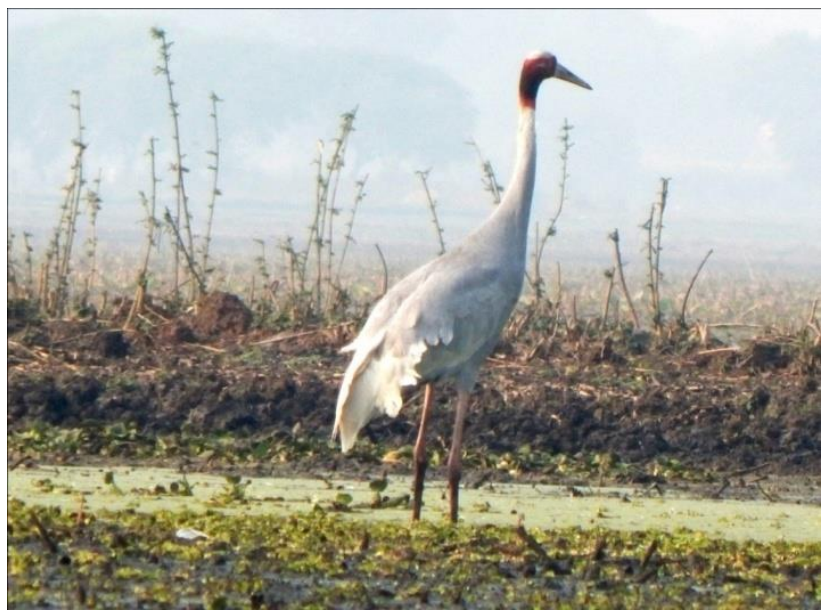

Fig. 2: Sarus Crane in Single (Solo) in Study Area

\section{Material and method}

The authors used binocular, camera, motorbike, chappu boat, field stick, etc. for various purposes. The findings are based upon the work conducted in all the 12 months in 2014. Investigations were conducted during first and third Sunday of every month, and investigation time was from 8 am to $6 \mathrm{pm}$. All the observations were made while moving through the chappu boat and walking along the croplands, mud lands, natural areas using binoculars (7x35 and 8x40-BEZIF BM-9) and canon cameras. Sights and calls were the devices to enlist a bird at a particular site.

Identification of different species was aided by using standard guides such as Ali (1941), Wild Life Institute of India wetland research methodology (1999) and Aryal et al, (2009). Besides actual sightings, local people were also interviewed to ensure the estimate of existing population and their perceptions about the existence, marital fidelity and congregation of the cranes under investigation. Exploration includes the survey of cranes as a single, pair, pair with one juvenile, pair with two juveniles and flocks comprising adults and juveniles. Since sarus crane is a huge bird and visible from a distance, we presume our counts almost accurate.

\section{Result and discussion}

Sarus is a social and omnivorous bird and during the study period, authors counted a congregation of maximum up to 155 cranes in evening in October 2014. This congregation occurs at particular and pre-decided sites, preferably in wetland area or adjacent agricultural fields having adequate food and water source. They have been seen in pairs everywhere (fig 3 and 4) even during flying or sitting or dancing or preening. They have also been seen with juvenile. The family group occurs in the whole year but during non-breeding season, cranes are seen in congregation for mate finding or pair formation. These cranes are involved in social displays to facilitate the pairing of unmated birds and to establish a pecking order among families. Male attracts the female to display dance like movement. The cranes were found to exist in solo condition rarely (fig 2).

Thus, congregation (fig 5 and 6 ) is not only meant for mate finding activity and safety but also prevented in mass from predating activities and harmful activities caused by aquatic animals, snakes and humans.

During our routine survey, especially on marital fidelity, authors came across many pairs and collected information about their courtship, dance, mating, fertilization, nest construction, egg lay- 
ing, hatching, juvenile care, growth of juvenile into young and rare occasions when a crane accidently dies, the behaviour of its partner. Interestingly enough, authors found that the other partner stops feeding after the death of its mate, starts crying in sorrow and ultimately dies.

In the study area, previously no such investigation and study were done on marital fidelity and the authors found that this behaviour

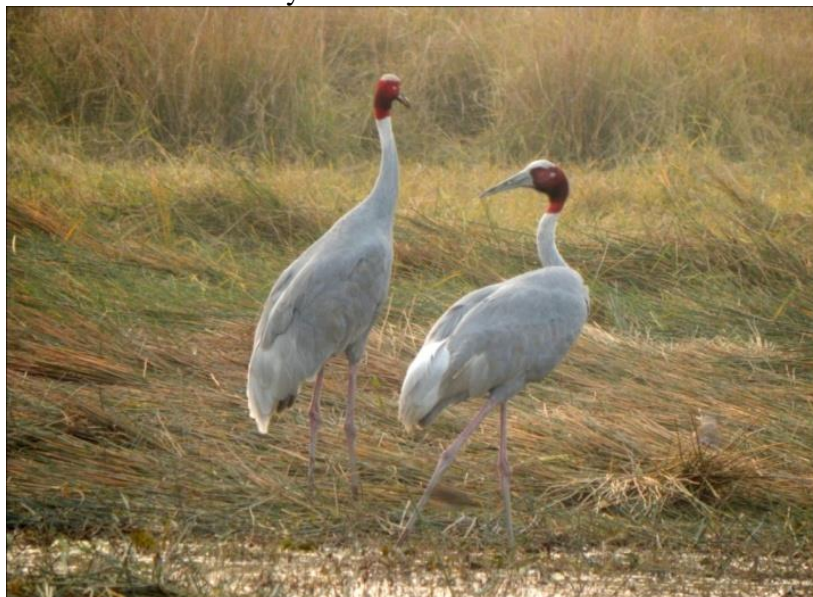

Fig. 3: Sarus Crane in Pair (Symbol of Marital Fidelity). is very unique as confirmed by local villagers around Alwara lake. The myth that cranes pair for life and in the event of the death of one bird the other stops feeding, cries hard and ultimately dies, is thus confirmed.

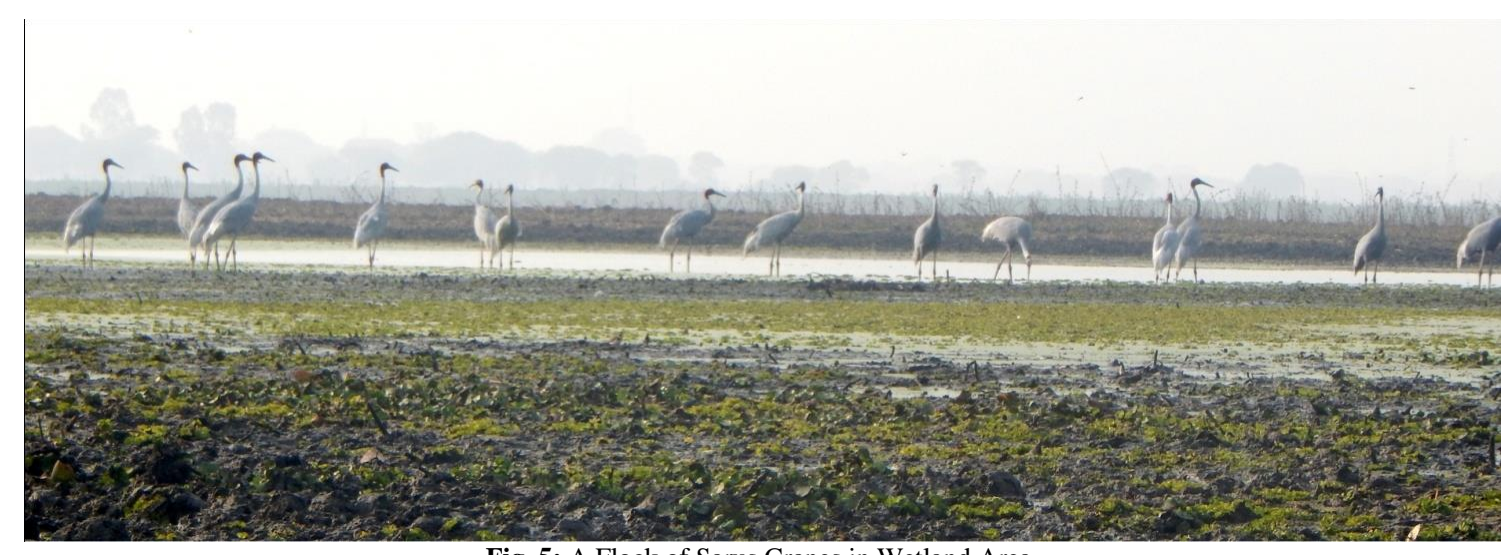

Fig. 5: A Flock of Sarus Cranes in Wetland Area.

Prakash et al, (2014) reported 335 cranes in total in and around Alwara Lake in 2012 while Verma et al, (2016) collected a data of 425 cranes in the same study area during 2013. In present survey, authors collected a data of more than 500 sarus cranes in 2014. This data is clearly indicating the increasing trends of sarus population growth from 2012 to 2014 . The reason behind the increase in population is due to openness, suitable agricultural land and seasonal marshes dominated over the climatic factors and occurrence of favourable ecological, feeding, mating and nesting conditions as well.

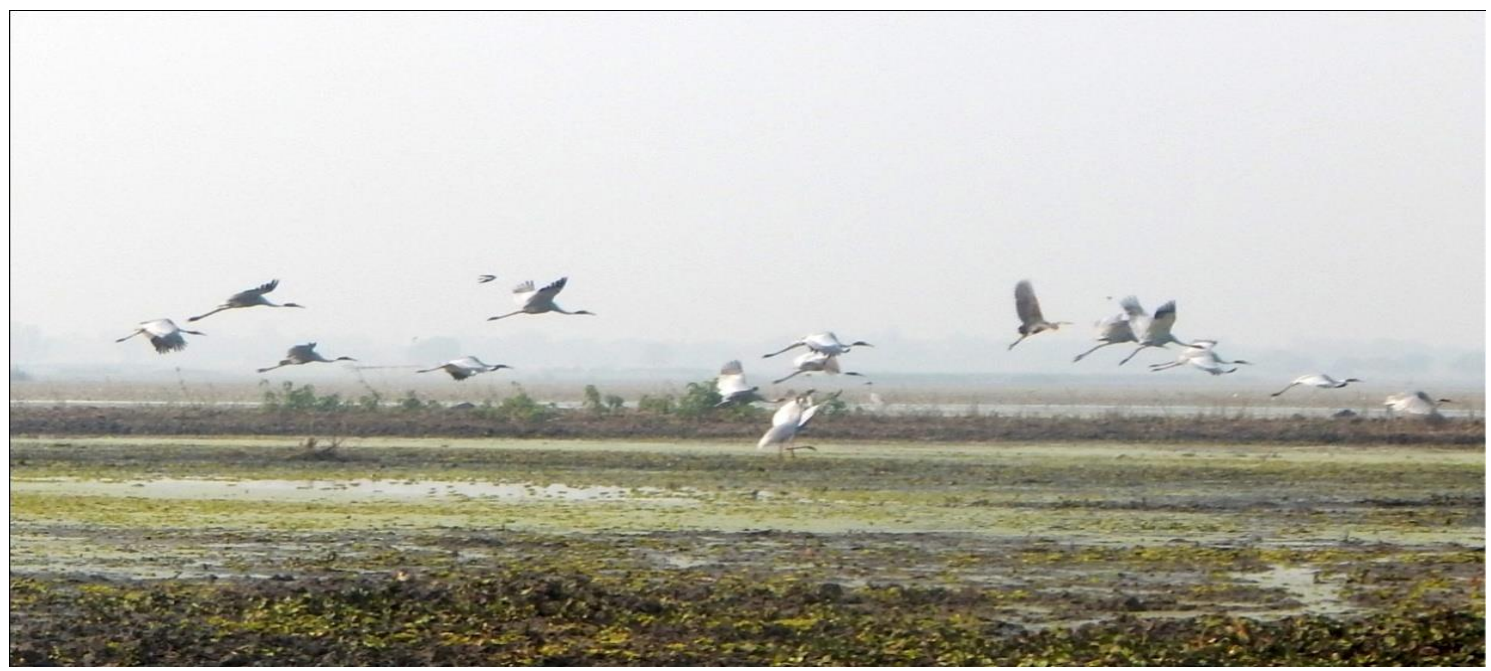

Fig. 6: Sarus Cranes in Flying Mode in Study Area. 


\section{Conclusion}

The Indian sarus crane has been listed as globally threatened i.e. vulnerable avian species (Bird Life International 2012) (IUCN, 2012) because of its declining numbers. Reasons behind this decline include decline in habitat quality, exploitation, pollution, competitors, parasites, etc. The increased anthropogenic activities, alterations in natural habitat and degradation of wetlands for agricultural expansion as well as for industrial development are the most serious threats to the cranes (Gole, 1989; Parasharya et al., 1989). As a consequence, the species has suffered a rapid population decline within a few decades (Choudhary 1999).The main challenge is to maintain their original or unaltered natural habitat. However, in the present study, an increasing trend is clearly noticed from 2012 to 2014. This is happening because this site is very favourable for sarus crane distribution from ecological point of view (Prakash et al, 2014; Verma et al, 2015). The authors found a congregation of maximum up to 155 cranes during the study period. The cranes can easily differentiate the local and harmless people from outsider and unknown people that may cause harm.

The cranes are well known for their faithfulness and living togetherness. Thus, sarus crane is an eternal symbol of unconditional love, devotion and good fortune with a high degree of marital fidelity as they mate for life.

The authors also recommend continuous population census of this species and declaration of the entire Alwara lake region as a "Sarus Safe Zone" for the conservation of sarus crane with regular monitoring and launching of awareness programmes.

\section{Acknowledgements}

Authors are highly grateful to Dr Jyoti Shankar, Principal K.A.P.G. College, Allahabad for providing necessary laboratory facilities and Dr Shubh Narain an eminent Zoologist for his assistance in various ways including manuscript preparation. One of authors (AKV) is extremely thankful to Dr Ram Chandra Misra Principal, Govt. P.G. College Saidabad Allahabad for continuous inspiration, encouragement, moral support, blessing and cooperation. Thanks are also to the administration of district Kaushambi, Uttar Pradesh to help during the survey programme.

\section{References}

[1] Ali, S. (1941). The Book of Indian Birds.The Bombay Natural Histural History Society, Bombay, $457 \mathrm{pp}$.

[2] Ali, S. and Ripley, S.D. (1980). "Hand book of the Birds of India and Pakistan", Vol. 2: Mega-Podes to Crab Plovers. J. Oxford University Press, Delhi.

[3] Ansari N.A. (2015). Population Composition and Distribution of Indian Sarus Crane Grus antigone antigone in Gautam Budh Nagar District, with special reference to Surajpur Wetland, National Capital Region, India. International Journal of Plant, Animal and Environmental Sciences. Volume-5, Issue-3, pp 41-46.

[4] Archibald, G. W.; Sundar, K.S.G. and Barzen, J. (2003). A review of the three subspecies of Sarus Cranes Grus antigone. Journal of Ecological Society. 16: 5-15.

[5] Aryal, A., Shrestha, T.K., Sen, D.S. Upreti B. and Gautam N. (2009). Conservation regime and local population ecology of Sarus Crane (Grus antigone antigone) in west-central region of Nepal. Journal of Wetlands Ecology 3: 1-11; http://dx.doi.org/10.3126/ jowe.v3i0.2224

[6] Bird Life International (2012). Grus antigone. IUCN Red List of Threatened Species. Version 2013.2. <www.iucnredlist.org>. Downloaded on 19 May 2014.

[7] Breeden, S., and Breeden, B. (1982). The drought of 1979-1980 at the Keoladeo Ghana Sanctuary, Bharatpur, Rajasthan. J. Bombay Natl. Hist. Soc. 79: 1-3.

[8] Chauhan, R. and Kumar D. (2000). A survey of Sarus cranes Grus antigone in Etawah and Mainpuri districts,Uttar Pradesh, India.
Technical Report, Society for Conservation of Nature Etawah (UP), India.

[9] Choudhary, H. (1999). Black-tailed Crake porzana bicolor: a new species for Nepal. Danphe 8(2/4): 4.

[10] Gole, P. (1989). The Status and Ecological Requirements of Sarus Crane. Phase I. Ecological Society, Pune, India. 45 pp.

[11] IUCN, (2012). "IUCN Red List of Threatened Species". IUCN, Gland, Switzerland.

[12] Jha, K.K. and McKinley C.R. (2014). Demography and Ecology of Indian Sarus Crane Grus antigone antigone in Uttar Pradesh, Northern India. Asian Journal of Conservation Biology 3(1), 8-18.

[13] Kumar, A. and Kanaujia, A. (2013). Congregation of Sarus Crane (Grus antigone) in Unnao District, Uttar Pradesh. International Journal of Science and Research. Vol. 4 (5), 1464-1465 pp.

[14] Meine, C.D. and Archibald, G.W. (1996). The Cranes:-Status survey and conservation action plan. IUCN, Gland, Switzerland and Cambridge, UK. 294 pp.

[15] Parasharya, B.M., Mathew, K.L. and Yadav, D.N. (1989). "Status and habitat preference of Indian Sarus Crane in Gujarat, India". Paper presented in the Asian Crane Congress at Rajkot, Gujarat, 1989.

[16] Prakash, S., Narain, S. and Kumar, S. (2014). Conservation of the threatened Sarus Crane Grus antigone (Linnaeus, 1758) around Alwara Lake in Kaushambi District, Uttar Pradesh, India. Journal of Threatened Taxa. 6: 5726-5730. http://dx.doi.org/10.11609/ JoTT.o3637.5726-30.

[17] Prasad, S.N., Ramachandran, N.K., Das, H.S. and Singh, D.F. (1993). "Sarus congregation in Uttar Pradesh". Newsletter for Birdwatchers, 33 (4), p 68.

[18] Sundar K.S.G., Chaudhary B.C. and Kaur J. (2000b). Distribution, demography and conservation status of the Indian Sarus Crane Grus antigone antigone in India. Journal Bombay Natural History Society 97, 319-339.

[19] Sundar, K.S.G. (2010). Sarus cranes in Uttar Pradesh. Kat's Eye 2, 2-4.

[20] Sundar, K.S.G. and Choudhary, B. C. (2003).The Indian Sarus Crane Grus a. antigone: a literature review. J. Ecol. Soc. (India) 16: 16-41.

[21] Sundar, K.S.G., Chaudhary B.C. and Kaur J. (2000a). Sarus crane count -2000. Wildlife Institute of India, Dehradun, India.

[22] Verma, A.K., Prakash, S. and Kumar Sunil (2015). Status and Ecology of Indian Sarus Crane, Grus antigone antigone in and around the Alwara Lake of District Kaushambi (U.P.). International Journal of Environmental Sciences 6(2): Jul-Dec. 331-335 pp.

[23] Verma, A.K., Prakash, S. and Kumar Sunil (2016). Increasing population trends of Indian Sarus Crane, Grus antigone antigone (Linnaeus, 1758) in and around Alwara Lake of District Kaushambi (U.P.), India. International Journal of Environmental Biology. Vol. $6(1)$.

[24] Verma, A.K. and Prakash, S. (2016). Demographic studies of Indian Sarus Crane, Grus antigone antigone in and around Alwara Lake of District Kaushambi (U.P.), India. International Journal of Innovative Biological Research 6(1).

[25] Wildlife Institute of India (1999). Training workshop on wetland research methodology measuring and monitoring biological diversity. WII. Dehra Dun, 5-10 pp. 